$\left[\begin{array}{lll}\text { 衛 } & \text { EISEI } & \text { 生 } \\ 30(2) & \text { KAGAKU } & \text { 学 } \\ 30-78 & (1984)\end{array}\right]$

\title{
銅化合物投与ラット臟器中の銅の分布と必須金属への影響
}

\author{
藤田昌彦，土屋恵子，高香英伍 \\ 国立公衆衛生院衛生薬学部
}

\section{Distribution of Copper and Interaction of Copper with Other Essential Metals in Rat after Oral Administration of Cupric Compounds}

\author{
Masahiko Fujita, Keiko Tsuchiya \\ and Eigo TAKaBATAKE \\ Institute of Public Health Shirokanedai, \\ Minatoku, Tokyo 108, Japan
}

(Received October 14, 1983)

\begin{abstract}
The distribution of copper in selected tissues and the metabolic interaction of copper with other essential metals were determined after oral administration of cupric carbonate, basic, and the results were compared with those of cupric sulfate. Male Wistar rats were orally administered for 2, 5, and $11 \mathrm{~d}$ with $0.5 \mathrm{mmol} / \mathrm{kg}$ of cupric compounds. Distribution of copper and change in essential metal levels were quantified by atomic absorption analysis. In the case of cupric carbonate, the copper was much more distributed in tissues, especially in the liver, than in that of cupric sulfate. Copper level increased progressively in mitochondria-lysosomal fraction of the liver in proportion to the period of administration.

In the $105000 \mathrm{~g}$ supernatant fraction, copper was distributed in metallothionein fraction rather than in superoxide dismutase fraction which had been considered as copper storage protein. The administration of cupric compounds resulted in an increase of zinc level in the liver, kidney, and spleen, preferentially in metallothionein fraction of the liver, but it seemed to affect little on iron metabolism.
\end{abstract}

Keywords — cupric carbonate; cupric sulfate; copper; zinc; iron; metallothionein; superoxide dismutase; liver; kidney; blood

\section{緒咅}

銅は古くから広範囲に使用されている金属で，身近な 例としては装飾品に, 調理器具にまた給水給晹管に使用 され，最近では高級食器としての需要も伸びている.こ れら銅製品を使用することにより，銅が体内に取り达ま れ，衛生上の危害を生ずる和それが考觉られる，そこで 食品衛生法では「銅製調理器具, 食器は銅固有の光沢を 有するものか，あるいは腐食によって生ずるさびを有し ないもの」と規定している.1この規定は緑青は銅その るのよりもはるかに猛毒であるといら古来の説に由来す るものと考えられるが，緑青の毒性に関する文献は臣と えどない.
本研究では緑青の主成分である塩基性炭酸銅の毒性を 明らかにするための一段階として強制的に塩基性炭酸銅 をラットに経口投与したときの体内分布及び必須金属で ある亜鉛，鉄の体内分布への影響を明らかにした。また 母乳代替食品に食品添加物として使用が認められた2゙硫 酸銅の体内分布と必須金属の体内分布への影響と比較し た.

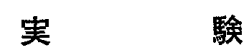

動物とその処置 ウィスター系雄性ラット（静岡罧 実験動物農業協同組合より購入）をコントロール群（体 重 $123.5 \pm 4.7 \mathrm{~g})$ ，硫酸銅投与群 $(125.8 \pm 3.7 \mathrm{~g})$, 塩基 性炭酸銅投与群 $(125.9 \pm 6.7 \mathrm{~g})$ に分忷，コントロール 
群には $5 \%$ アラビアゴム水溶液を $2 \mathrm{ml} / \mathrm{kg}$ 体重の割合で 硫酸銅投与群飞は硫酸銅(和光純薬裂特級, $\mathrm{CuSO}_{4}$. $\left.5 \mathrm{H}_{2} \mathrm{O}\right)$ の水溶液を $0.5 \mathrm{mmol}(31.7 \mathrm{mg} \mathrm{Cu}) / 2 \mathrm{ml} / \mathrm{kg}$ 体 重の割合で，塩基性炭酸銅投与群には塩基性炭酸銅（関 東化学製，特級， $\left.\mathrm{CuCO}_{3} \cdot \mathrm{Cu}(\mathrm{OH})_{2} \cdot \mathrm{H}_{2} \mathrm{O}\right)$ を $5 \%$ ア ビアゴム水溶液に繋濁した溶液を $0.5 \mathrm{mmol}(63.5 \mathrm{mg}$ $\mathrm{Cu}) / 2 \mathrm{ml} / \mathrm{kg}$ 体重の割合で, 1 日 1 回強制経口投与し た。投与期間は 2 日， 5 日または 11 日とし，最終投与 24 時間後に心淢から脱血して殺した。

肝臓は生理食塩水で灌流した後, 摘出し, $1.15 \% \mathrm{KCl}$ $50 \mathrm{~mm}$ Tris-HCl (pH 7.4) 中でホモジナイズし, 常法 に従ってミトコンドリフ・ライソンーム画分, ミクロソ 一ム画分, サイトソール画分に分画した。

分析法血液・臓器中の金属濃度は硝酸・過塩素酸 で分解した後, 日立フレーム型原子吸光光度計 207 型で 測定した。

ゲルろ過クロマトグラフィーは Sephadex G-100をつ めたカラム $(28 \phi \times 480 \mathrm{~mm})$ にサイトソール $4.0 \mathrm{mi}$ のせ, 緩衝液 (0.02 м Tris-HCl, pH 8.6,0.005 м 2ルカプトェタノール, $0.05 \mathrm{M} \mathrm{KCl}, 0.003 \mathrm{M} \mathrm{NaN}_{3}$ ) で, 流速 $0.3 \mathrm{ml} / \mathrm{min}$ で溶出し, 100 滴/ 1 画分ずつ分取し た。溶出液中の重金属濃度は溶出液をフレーム型原子吸 光光度計にそのま先霧して测定した。

ゲルろ過クロマトグラムの分子量同定は, ベーリンガ 一・マンハイム山之内社製分子量測定用標準タンパク犋 キット(チトクロームC：分子量12000, キモトリプシ， ーゲンA:25000, オバルブミン: 45000, アルブミン: 68000 ，カタラーゼ: 240000）を用いて行なった。

\section{結果}

銅化合物投与を続けると，体重に対する肝臓の比重量 は減少した（Table I). 特に壏基性炭酸銅投与群の力
が硫酸銅投与群より影響がやや顕著であった。同様な傾 向は腎蔵に执いてもみられたが，脾蔵ではほとんど変化 がみられなかった。

次に血液及び藏器中の銅の分布を Table II に示し た。血中の銅濃度は投与 5 日後から有意に増加したが， 増加の割合は小さかった。これに対し，肝臓中の銅濃度 は投与 2 日後から急速に增加し, その増加の割合は硫酸 銅投与群より塩基性炭酸銅投与群の方が著しかった。塩 基性炭酸銅投与 11 日後には銅濃度は雨鉛濃度よりはるか に高濃度となった。対照動物群の腎臟中の銅濃度は肝臓 に比して高く，約 2 倍量の銅が含をれていた。これに銅 化合物を投与すると，銅濃度は有意に増加したが，肝臓 中の銅濃度㴗ど増加しなかった。ここでる塧基性炭酸銅 投与群の方が多量の銅艺蓄積した。脾臓の銅濃度は銅化 合物投与によってわずかに增加したにすぎなかった。

つぎに肝細胞内の銅の分布をみるために，肝蔵のホモ ジネートを遠心分画し, 各画分中の金属濃度を測定し, 肝臓 $1 \mathrm{~g}$ 当りの濃度に換算した。対照群の肝藏中の銅は サイトソール画分中に最多多く分布していた．銅化合物 を投与すると，この画分中の銅濃度も增加したが，そ尗 にも李してミトコンドリア・ライソソーム画分中の銅濃 度が増加した， その增加の割合は硫酸銅投与群上りも塩 基性炭酸銅投与群の方が顕著であった。ミクロソーム画 分中の銅濃度飞銅化合物投与日数に比例して増加した が，わずかであった。銅化合物投与によるミクロソーム 画分中の銅濃度の増加㤝わずかであるというこれまでの 報告 ${ }^{3-5)}$ と一致していた。腎藏についてはサイトソール への銅の分布を調べた、対照群の等臓中の銅は約 $80 \%$ が サイトソール画分中に分布しており肝藏の場合よりはる かに高い值であった，銅化合物を投与するとサイトソー ル画分中の銅濃度は $1.7-2.0$ 倍に增加した。これは肝

TABLE I. Effect of Cupric Compounds on Relative Organ Weight to Body Weight

(g/100 g body weight)

\begin{tabular}{lrlll}
\hline \multicolumn{1}{c}{ Treatment } & & \multicolumn{1}{c}{ Liver } & Kidney & Spleen \\
\hline Control & & $5.33 \pm 0.60$ & $1.56 \pm 0.07$ & $0.24 \pm 0.03$ \\
$\mathrm{CuSO}_{4}$ & $2 \mathrm{~d}$ & $5.18 \pm 0.13$ & $1.49 \pm 0.07$ & $0.24 \pm 0.03$ \\
$\mathrm{CuSO}_{4}$ & $5 \mathrm{~d}$ & $4.97 \pm 0.10^{a)}$ & $1.44 \pm 0.09$ & $0.27 \pm 0.03$ \\
$\mathrm{CuSO}_{4}$ & $11 \mathrm{~d}$ & $4.98 \pm 0.61$ & $1.63 \pm 0.06$ & $0.26 \pm 0.01$ \\
$\mathrm{CuCO}_{3} \mathrm{Cu}(\mathrm{OH})_{2}$ & $2 \mathrm{~d}$ & $5.15 \pm 0.22$ & $1.03 \pm 0.05^{b}$ & $0.23 \pm 0.02$ \\
$\mathrm{CuCO}_{3} \mathrm{Cu}(\mathrm{OH})_{2}$ & $5 \mathrm{~d}$ & $4.96 \pm 0.46^{a)}$ & $\left.1.23 \pm 0.19^{j}\right)$ & $0.26 \pm 0.01$ \\
$\mathrm{CuCO}_{3} \mathrm{Cu}(\mathrm{OH})_{2}$ & $11 \mathrm{~d}$ & $4.66 \pm 0.32^{a)}$ & $1.61 \pm 0.17$ & $0.23 \pm 0.01$
\end{tabular}

Values are means \pm standard deviations of 5 rats for each group.

Rats were orally given a solution of cupric sulfate $(0.5 \mathrm{mmol} / \mathrm{kg}$ body weight) or a suspension of cupric carbonate in $5 \%$ arabic gum solution $(0.5 \mathrm{mmol} / \mathrm{kg}$ body weight) once a day for above period.

a) Significantly different from control group, $p<0.05$.

b) Significantly different from control groun, $p<0.01$. 
TABLE II. Concentration of Copper in Blood and Some Tissues after Oral Administration of Cupric Compounds

( $\mu \mathrm{g} \mathrm{Cu} / \mathrm{g}$ wet weight)

\begin{tabular}{|c|c|c|c|c|c|c|}
\hline Treatment & & Blood & Hematocyte ${ }^{(s)}$ & Plasma $^{c)}$ & Liver & Liver cytosol \\
\hline Control & & $0.83 \pm 0.04$ & 0.68 & 0.83 & $4.0 \pm 0.7$ & $2.05 \pm 0.19$ \\
\hline \multirow[t]{3}{*}{$\mathrm{CuSO}_{4}$} & $2 \mathrm{~d}$ & $0.92 \pm 0.05$ & nd & nd & $8.7 \pm 0.8^{\alpha)}$ & $3.13 \pm 0.43^{(a)}$ \\
\hline & $5 \mathrm{~d}$ & $1.01 \pm 0.03^{a)}$ & 0.60 & 0.90 & $19.8 \pm 5.9^{a)}$ & $4.55 \pm 0.81^{a)}$ \\
\hline & $11 \mathrm{~d}$ & $1.11 \pm 0.24$ & 0.56 & 1.05 & $22.9 \pm 5.5^{a)}$ & $5.55 \pm 2.20^{b)}$ \\
\hline \multirow[t]{3}{*}{$\mathrm{CuCO}_{3} \mathrm{Cu}(\mathrm{OH})_{2}$} & $2 \mathrm{~d}$ & $0.97 \pm 0.12$ & 0.64 & 1.05 & $33.0 \pm 5.2^{a)}$ & $4.70 \pm 0.89^{a)}$ \\
\hline & $5 \mathrm{~d}$ & $1.03 \pm 0.05^{a 2}$ & 0.55 & 0.60 & $72.6 \pm 8.3^{a)}$ & $6.78 \pm 1.16^{a)}$ \\
\hline & $11 \mathrm{~d}$ & $1.06 \pm 0.03^{a)}$ & 0.60 & 1.00 & $98.9 \pm 3.7^{a)}$ & $7.89 \pm 1.71^{a)}$ \\
\hline \multicolumn{2}{|l|}{ Treatment } & $\begin{array}{c}\text { Liver } \\
\text { microsome }\end{array}$ & $\begin{array}{l}\text { Liver } \\
\text { mitochondria }\end{array}$ & Kidney & Kidney cytosol & Spleen \\
\hline \multicolumn{2}{|l|}{ Control } & $0.21 \pm 0.01$ & $0.90 \pm 0.09$ & $8.00 \pm 1.83$ & $6.38 \pm 1.09$ & $1.18 \pm 0.10$ \\
\hline \multirow[t]{3}{*}{$\mathrm{CuSO}_{4}$} & $2 \mathrm{~d}$ & $0.44 \pm 0.02^{a)}$ & $5.60 \pm 1.35^{a)}$ & $8.93 \pm 1.59$ & $6.29 \pm 0.84$ & $1.03 \pm 0.13$ \\
\hline & $5 d$ & $0.55 \pm 0.21^{6)}$ & $14.08 \pm 4.19^{a)}$ & $11.30 \pm 0.96^{b)}$ & $9.19 \pm 0.80^{a)}$ & $1.60 \pm 0.18$ \\
\hline & $11 \mathrm{~d}$ & $0.75 \pm 0.03^{a)}$ & nd & $11.00 \pm 3.50$ & $10.01^{c>}$ & $1.32 \pm 0.03$ \\
\hline \multirow[t]{3}{*}{$\mathrm{CuCO}_{3} \mathrm{Cu}(\mathrm{OH})_{2}$} & $2 \mathrm{~d}$ & $0.76 \pm 0.14^{(a)}$ & $16.97 \pm 0.35^{a)}$ & $8.98 \pm 1.92$ & $6.82 \pm 1.70$ & $1.20 \pm 0.01$ \\
\hline & $5 \mathrm{~d}$ & $\left.1.18 \pm 0.29^{a}\right)$ & $35.00 \pm 1.59^{a)}$ & $16.02 \pm 2.24^{a)}$ & $13.57 \pm 0.72^{\alpha)}$ & $1.60 \pm 0.13$ \\
\hline & $11 \mathrm{~d}$ & $1.45 \pm 0.65$ & $\mathrm{nd}$ & $18.70 \pm 1.30^{a)}$ & $13.20^{c)}$ & $1.40 \pm 0.09^{b)}$ \\
\hline
\end{tabular}

The experimental details are as described in Table $I$.

The results represent means $\pm S D$ for 5 rats.

Significantly different from control, a) $p<0.01, b) p<0.05$.

c) Result for pooled sample for each group.

nd $:$ not determined.

Table III. Concentration of Zinc in Blood and Some Tissues after Oral Administration of Cupric Compounds ( $\mu \mathrm{g} \mathrm{Zn/g} \mathrm{wet} \mathrm{weight)}$

\begin{tabular}{|c|c|c|c|c|c|c|}
\hline Treatment & & Blood & Hematocyte ${ }^{c)}$ & Plasma & Liver & Liver cytosol \\
\hline Control & & $4.79 \pm 0.72$ & 6.75 & 2.10 & $20.9 \pm 2.8$ & $16.5 \pm 2.7$ \\
\hline \multirow[t]{3}{*}{$\mathrm{CuSO}_{4}$} & $2 \mathrm{~d}$ & $5.15 \pm 0.13$ & nd & nd & $22.2 \pm 1.7$ & $18.7 \pm 1.5$ \\
\hline & $5 \mathrm{~d}$ & $5.82 \pm 0.07^{b)}$ & 5.85 & 2.70 & $28.7 \pm 2.1^{b)}$ & $23.9 \pm 1.4^{a)}$ \\
\hline & $11 \mathrm{~d}$ & $5.60 \pm 0.22$ & 6.06 & 2.70 & $26.0 \pm 3.5$ & $22.9 \pm 1.4^{a)}$ \\
\hline \multirow[t]{3}{*}{$\mathrm{CuCO}_{3} \mathrm{Cu}(\mathrm{OH})_{2}$} & $2 \mathrm{~d}$ & $5.15 \pm 0.59$ & 6.20 & 2.80 & $22.1 \pm 1.3$ & $19.1 \pm 1.7$ \\
\hline & $5 \mathrm{~d}$ & $5.24 \pm 0.06$ & 5.80 & 2.85 & $30.8 \pm 5.8$ & $26.2 \pm 7.1^{b 2}$ \\
\hline & $11 \mathrm{~d}$ & $5.50 \pm 0.12$ & 6.50 & 3.35 & $23.9 \pm 2.0$ & $20.6 \pm 1.9^{b)}$ \\
\hline \multicolumn{2}{|l|}{ Treatment } & $\begin{array}{l}\text { Liver } \\
\text { microsome }\end{array}$ & $\begin{array}{c}\text { Liver } \\
\text { mitochondria }\end{array}$ & Kidney & Kidney cytosol & Spleen \\
\hline \multicolumn{2}{|l|}{ Control } & $2.55 \pm 0.24$ & $3.95 \pm 0.19$ & $19.7 \pm 5.2$ & $17.0 \pm 1.6$ & $18.6 \pm 3.0$ \\
\hline \multirow[t]{3}{*}{$\mathrm{CnSO}_{4}$} & $2 \mathrm{~d}$ & $2.48 \pm 0.54$ & $4.65 \pm 0.19^{a)}$ & $19.0 \pm 2.4$ & $18.5 \pm 1.2$ & $14.0 \pm 2.1$ \\
\hline & $5 d$ & $2.95 \pm 0.27$ & $5.95 \pm 1.01^{b)}$ & $26.9 \pm 1.2^{b 3}$ & $21.0 \pm 0.5^{a)}$ & $22.3 \pm 2.5$ \\
\hline & $11 \mathrm{~d}$ & $2.33 \pm 0.25$ & nd & $26.3 \pm 1.0^{b 3}$ & $21.8^{(2)}$ & $21.0 \pm 0.8$ \\
\hline \multirow[t]{3}{*}{$\mathrm{CuCO}_{3} \mathrm{Cu}(\mathrm{OH})_{2}$} & $2 \mathrm{~d}$ & $2.70 \pm 0.10$ & $4.50 \pm 0.20^{a)}$ & $17.1 \pm 1.5$ & $16.4 \pm 0.9$ & $17.2 \pm 0.6$ \\
\hline & $5 \mathrm{~d}$ & $2.88 \pm 0.35$ & $4.95 \pm 0.38^{a)}$ & $26.4 \pm 1.2^{b)}$ & $20.2 \pm 0.7$ & $21.0 \pm 0.5$ \\
\hline & $11 \mathrm{~d}$ & $2.00 \pm 0.20^{a)}$ & nd & $26.7 \pm 1.3^{b)}$ & $18.3^{(c)}$ & $21.1 \pm 1.1$ \\
\hline
\end{tabular}

The experimental details are as described in Table I.

The results represent means $\pm \mathrm{SD}$ for 5 rats.

Significantly different from control, a) $p<0.01, b) p<0.05$.

c) Result for pooled sample for each group.

nd : not determined. 
TABLE IV. Concentration of Iron in Blood and Some Tissues after Oral Administration of Cupric Compounds

( $\mu \mathrm{g} \mathrm{Fe} / \mathrm{g}$ wet weight)

\begin{tabular}{|c|c|c|c|c|c|c|}
\hline Treatment & & Blood & Hematocyte $\mathrm{e}^{c)}$ & Plasma ${ }^{c)}$ & Liver & Liver cytosol \\
\hline Control & & $386.0 \pm 94.2$ & 730.0 & 1.6 & $44.6 \pm 5.3$ & $10.0 \pm 1.6$ \\
\hline \multirow[t]{3}{*}{$\mathrm{CuSO}_{4}$} & $2 \mathrm{~d}$ & $284.2 \pm 60.2$ & nd & nd & $38.0 \pm 8.8$ & $8.7 \pm 1.7$ \\
\hline & $5 \mathrm{~d}$ & $402.7 \pm 32.6$ & 698.5 & 3.6 & $36.9 \pm 7.9$ & $10.7 \pm 0.9$ \\
\hline & $11 \mathrm{~d}$ & $445.1 \pm 85.0$ & 581.7 & 2.0 & $34.9 \pm 8.6$ & $10.7 \pm 3.7$ \\
\hline \multirow{3}{*}{$\mathrm{CuCO}_{3} \mathrm{Cu}(\mathrm{OH})_{2}$} & $2 \mathrm{~d}$ & $305.3 \pm 12.2$ & 640.0 & 5.6 & $34.4 \pm 4.3^{b)}$ & $8.1 \pm 1.3$ \\
\hline & $5 d$ & $371.1 \pm 25.5$ & 571.0 & 2.1 & $36.7 \pm 6.0$ & $7.9 \pm 1.7$ \\
\hline & $11 \mathrm{~d}$ & $389.6 \pm 66.8$ & 715.0 & 2.7 & $47.6 \pm 36.9$ & $10.0 \pm 8.2$ \\
\hline \multicolumn{2}{|l|}{ Treatment } & $\begin{array}{l}\text { Liver } \\
\text { microsome }\end{array}$ & $\begin{array}{c}\text { Liver } \\
\text { mitochondria }\end{array}$ & Kidney & Kidney cytosol & Spleen \\
\hline \multicolumn{2}{|l|}{ Control } & $19.0 \pm 3.5$ & $10.4 \pm 0.4$ & $33.9 \pm 1.7$ & $17.1 \pm 2.3$ & $180.1 \pm 16.2$ \\
\hline \multirow[t]{3}{*}{$\mathrm{CuSO}_{4}$} & $2 \mathrm{~d}$ & $17.1 \pm 6.4$ & $10.2 \pm 2.8$ & $30.8 \pm 3.5$ & $13.4 \pm 1.3^{b)}$ & $132.4 \pm 11.4^{a)}$ \\
\hline & $5 \mathrm{~d}$ & $16.7 \pm 2.6$ & $8.8 \pm 1.1$ & $31.2 \pm 1.5$ & $14.5 \pm 0.4$ & $168.4 \pm 26.1$ \\
\hline & $11 \mathrm{~d}$ & $13.0 \pm 5.8$ & nd & $34.0 \pm 10.4$ & $16.0 \pm 2.3$ & $177.0 \pm 0.0$ \\
\hline \multirow[t]{3}{*}{$\mathrm{CuCO}_{3} \mathrm{Cu}(\mathrm{OH})_{2}$} & $2 d$ & $18.0 \pm 0.8$ & $8.5 \pm 0.8^{b)}$ & $28.8 \pm 4.0$ & $13.4 \pm 1.4^{b)}$ & $188.8 \pm 44.3$ \\
\hline & $5 d$ & $13.9 \pm 2.6$ & $7.2 \pm 1.0^{a)}$ & $28.2 \pm 1.2^{a)}$ & $11.6 \pm 2.0^{a)}$ & $156.5 \pm 22.3$ \\
\hline & $11 \mathrm{~d}$ & $19.6 \pm 23.3$ & nd & $32.9 \pm 4.3$ & $10.5 \pm 2.3^{a)}$ & $166.8 \pm 39.5$ \\
\hline
\end{tabular}

The experimental details are as described in Table I.

The results represent means \pm SD for 5 rats.

Significantly different from control, $a) p<0.01, b) p<0.05$.

c) Result for pooled sample for each group.

nd : not determined.

サイトソール中の銅濃度の增加（2.7-3.8倍）よりも 少なかった。

Table III に必須元素である亚鉛濃度に対する 銅化合 物投与の影響を示した．血中の亜鉛濃度は銅濃度と同様 に銅化合物投与によって増加の傾向がみられた。乙か し，その增加の割合は銅濃度の増加の割合よりも小さか った。肝臓中の正鈶濃度も血中の場合と同様に増加の傾 向がみられたが，その増加は有意ではなかった。腎臟中 の亜鉛漂度は銅化合物投与 2 日後では変動がみられなか ったが，5日後からは有意に増加し，約 $26 \mu \mathrm{g} / \mathrm{g}$ という 平衡濃度に達した．京た，脾臓中の亜鉛濃度も銅化合物 投与によって增加の傾问がみられたが，有意ではなかっ た。

肝細胞内画分中の西鉛濃度はミクロソーム画分中では 銅化合物投与によってもほとんど変らなかったが，サイ トソール画分中では有意に增加した。また，ミトコンド リア・ライソソーム画分中でも有意に增加したが，鉰濃 度の増加程ではなかった。

腎藏中の㺿鉛は対照動物群で約 $86 \%$ がサイトソール画 分中に分布し，銅化合物投与によってサイトソール画分 中の亜鉛濃度も增加した。

また，必須元素である鉄の血液，臓器中濃度への銅化
合物投与の影響を Table IV に示した。銅化合物投与 2 日後には血中鉄濃度は顕著に減少したが，その後鉄濃 度は回復し，硫酸銅投与群では対照群よりわずかに高い 値にまで上昇した，肝臓，腎葴及び脾臓中の鉄湄度は血 中鉄濃度と類似した変動を示した。いずれの臓器でも硫 酸銅投与 2 日後に䫒著な鉄濃度の減少がみられた。

旰細胞内画分中の鉄湄度は肝藏中の鉄濃度の变動と掠 和よそ同じ動きを示したが，腎サイトソール中の鉄濃度 は塩基性炭酸銅投与によって大きく低下した。

肝臓のサイトソールを Sephadex G-100でゲルろ過す ると，銅は大きく 3 つた゚ークに，要鉛は 4 つのピーク に分孔た．鉄は高分子量画分に 1 つピークとなって分 布した。典型的なゲルろ過クロマトグラムを Fig.1 に 示した. そこで分子量 100000 以上の $\mathrm{A}$ 画分 $(\mathrm{Ve} / \mathrm{Vo}=$ $1.00)$, 分子量約 30000 D 画分 $(\mathrm{Ve} / \mathrm{Vo}=1.25)$ 之分 子量約 $100000 \mathrm{C}$ 画分 $(\mathrm{Ve} / \mathrm{Vo}=1.78)$ の 3 D画分 に分け，とれぞれの画分中の銅，亜鉛合量を測定し，銅 化合物投与期間との関係を解析した。

これら各画分中の銅含量に対する銅化合物投与の影響 を多ると (Table V), A画分中の銅は銅化合物投与によ りわずかに增加の傾向がみられたが，その堌加は有意で はなかった．対照動物群ではB画分中に銅の大部分（92 

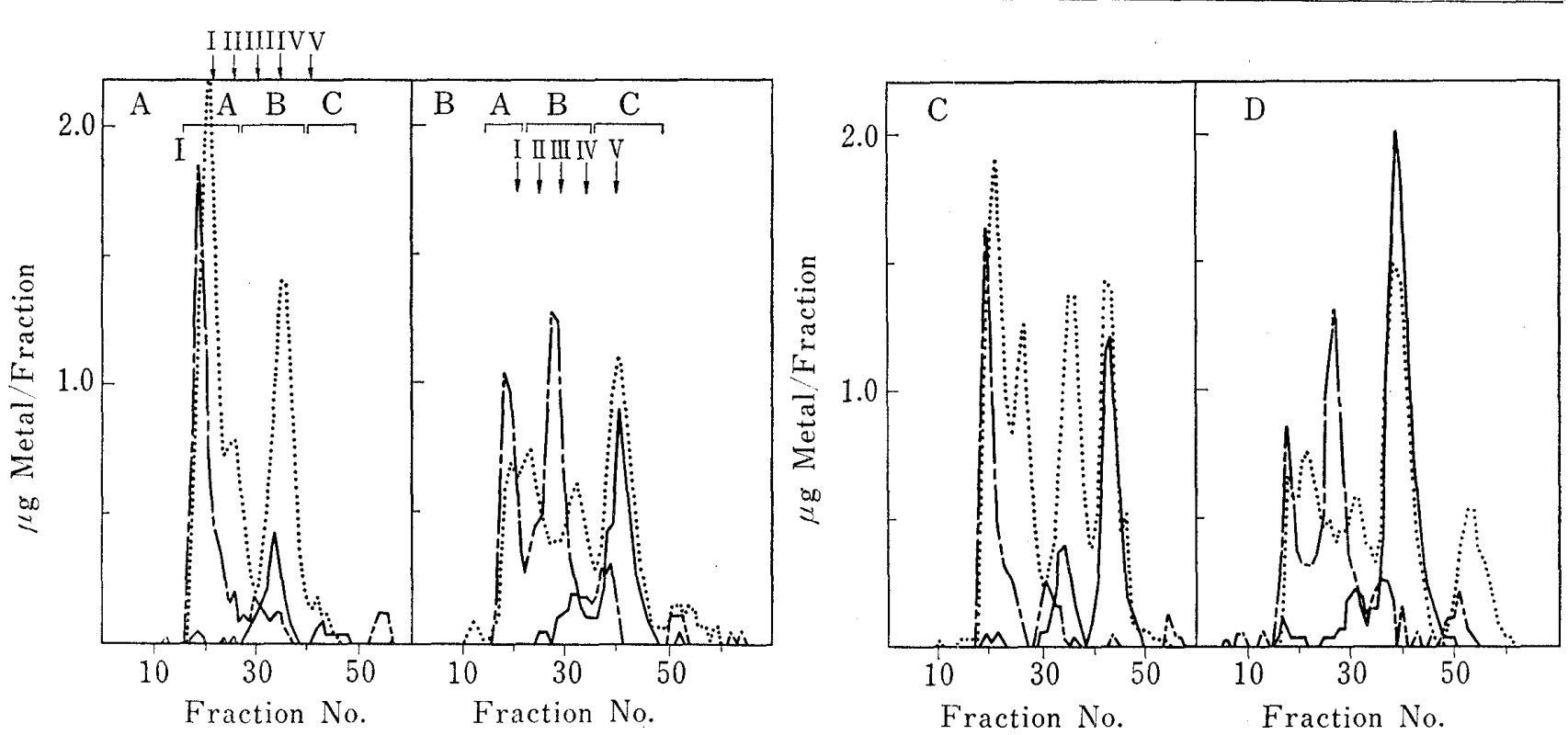

Fig. 1. Elution Profile of Hepatic and Renal Cytosol Obtained from Control Rat and Cupric Carbonate-Loaded Rat on a Sephadex G-100 Column

The rat was orally administered with cupric compound on a dose of $0.5 \mathrm{mmol} / \mathrm{kg} / \mathrm{d}$ once a day for 2,5 , and $11 \mathrm{~d}$. The rat was killed $24 \mathrm{~h}$ after the last administration and the tissue was homogenized in $1.15 \%$ $\mathrm{KCl}-0.05 \mathrm{M}$ Tris- $\mathrm{HCl}(\mathrm{pH} 7.4)$. The homogenate was fractionated by differential centrifugation at $4^{\circ} \mathrm{C}$ in Hitachi 20PR-5 refrigerated centrifuge and $55 \mathrm{P}$-ultracentrifuge into the following fractions; nuclear-consisting of nuclei, unbroken cell and cell debris $(600 \mathrm{~g}, 10 \mathrm{~min})$; mitochondrial-consisting of mitochondria and lysosomes $(24500 \mathrm{~g}, 10 \mathrm{~min})$; microsomal- $(105000 \mathrm{~g}, 1 \mathrm{~h}$ ); cytosolic-(supernatant fraction from microsomal fraction). A $4 \mathrm{ml}$ portion of cytosol was applied on a Sephadex G-100 column $(28 \times 480 \mathrm{~mm})$. The column was eluted with a buffer $\left(0.02 \mathrm{~m}\right.$ Tris- $\mathrm{HCl}, \mathrm{pH} 8.6,0.005 \mathrm{M}$ 2-mercaptoethanol-0.05 $\left.\mathrm{M} \mathrm{KCl}-0.003 \mathrm{~m} \quad \mathrm{NaN}_{3}\right)$ and 100 drops fraction was collected. Metal concentration in each fraction was determined with a flame type atomic absorption spectrometer. The allows (I, II, III, IV and V) indicated the eluted positions of catalase (MW 240000), albumin (68000), ovalbumin (45000), chymotrypsinogen A (25000) and cytochrome C (12000), respectively. A ; control rat liver, B; control rat kidney, C ; cupric carbonate-loaded rat liver for $5 \mathrm{~d}$, D ; cupric carbonateloaded rat kidney for $5 \mathrm{~d}$.

$$
\text { - : Cu. } \quad \cdots \cdots: \mathrm{Zn} . \quad-\cdot-\mathrm{E} \text { : Fe. }
$$

\%)が分布していたが，銅化合物投与によってもB画分 中の銅濃度はほとんぞ增加しなかった，一方，C画分中 の銅濃度は銅化合物投与によって大きく增加し，硫酸銅 投与11日後には対照群の25倍, 塩基性炭酸銅投与の場合 は58倍となった．従ってB画分中の銅濃度の全肝濃度に 占める割合は大きく低下した。

次に，亜鉛のサイトソール画分中の分布をみると (Table V), 対照群では高分子量画分 (A) 中に $55 \%$ の亜鉛が分布し，ついでB画分に多く分布していた.こ れに銅化合物を投与すると A及び $\mathrm{B}$ 画分中の亜鉛含量は ほとんど変動がみられなかったが，メタロチオネインを 含むC画分中の亜鉛量は有意に增加した．しかし，この ようにC画分中の亜鉛量が增加しても，サイトソール中 の亜鉛の大部分はA画分 (48-49\%) 及びB 画分（3034\%）に分布していた。

鉄はほとえどA画分に存在し，銅化合物投与によって も分布の移動は認められなかった。

腎臓サイトソール中の銅の分布（Table VI）をみる
之，肝臟とは大きく異なって対照動物群で銅の大部分 (78\%) が，C画分に分布していた. ついでB画分に 18.5\%の銅が分布していた。これに銅化合物を投与する と,メタロチオネイン (MT) を含むC画分中の銅が有 意に増加したが，A及び $\mathrm{B}$ 画分中の銅濃度はほとんど增 加がみられなかった。

腎サイトソール中の亜鉛はA画分に最も多く分布し， 次に $34 \%$ の亜鉛がC画分に分布していた．銅化合物を投 与すると， A， B 及びC 画分中の亜鉛量はそれぞれ增加 したが，特にC画分中の亜鉛量の増加が大きく，A画分 中の亜鉛量よりる多くなった。しかし，关の増加は肝臓 中の亜鉛の增加に比べるとはるかに小さい，

対照動物群の鉄の分布は肝臓の場合と大きく樣相を異 にしていた．肝臓ではA画分に1つの大さなピークとし て分布していたが，腎臓ではB画分に大きなピーク，そ れより少し小さなピークがA画分に，そして小さな広が ったピークが低分子量画分に存在していた。これらの鉄 の分布に対しては銅化合物投与の影響はほとんどみられ 
$T_{A B L E}$ V. Subcellular Distribution ${ }^{b)}$ of Copper and Zinc in Hepatic Cytosol after Oral Administration of Cupric Compounds

( $\mu \mathrm{g} \mathrm{Metal} / \mathrm{g}$ liver)

\begin{tabular}{|c|c|c|c|c|c|c|c|}
\hline \multirow{2}{*}{ Treatment ${ }^{a}$ ) } & & \multicolumn{3}{|c|}{ Copper } & \multicolumn{3}{|c|}{ Zinc } \\
\hline & & Fr. $A^{c)}$ & Fr. B & Fr. C & Fr. A & Fr. B & Fr. C \\
\hline Control & & $0.04 \pm 0.03$ & $1.81 \pm 0.26$ & $0.11 \pm 0.11$ & $10.06 \pm 1.33$ & $7.90 \pm 1.21$ & $0.34 \pm 0.33$ \\
\hline $\mathrm{CuSO}_{4}$ & $\begin{array}{r}2 \mathrm{~d} \\
5 \mathrm{~d} \\
11 \mathrm{~d}\end{array}$ & $\begin{array}{c}0.11 \pm 0.05 \\
0.13 \pm 0.09 \\
0.32^{f}\end{array}$ & $\begin{array}{c}2.14 \pm 0.18 \\
2.08 \pm 0.19 \\
\left.1.83^{f}\right)\end{array}$ & $\begin{array}{c}1.10 \pm 0.29^{e)} \\
2.50 \pm 0.94^{e)} \\
2.52^{f)}\end{array}$ & $\begin{array}{c}11.22 \pm 2.79 \\
12.54 \pm 0.85 \\
\left.10.53^{f}\right)\end{array}$ & $\begin{array}{c}8.07 \pm 0.78 \\
7.40 \pm 0.67 \\
7.49^{f)}\end{array}$ & $\begin{array}{c}3.71 \pm 0.81^{e)} \\
5.38 \pm 1.12^{e)} \\
3.87^{f)}\end{array}$ \\
\hline $\mathrm{CuCO}_{3} \mathrm{Cu}(\mathrm{OH})_{2}$ & $\begin{array}{r}2 \mathrm{~d} \\
5 \mathrm{~d} \\
11 \mathrm{~d}\end{array}$ & $\begin{array}{c}0.14 \pm 0.06^{(d)} \\
0.19 \pm 0.12 \\
0.77^{f)}\end{array}$ & $\begin{array}{c}2.33 \pm 0.12^{d)} \\
2.22 \pm 0.32 \\
1.96^{f)}\end{array}$ & $\begin{array}{c}2.86 \pm 0.71^{e)} \\
4.40 \pm 0.81^{e)} \\
5.86^{f)}\end{array}$ & $\begin{array}{c}10.17 \pm 1.08 \\
11.97 \pm 1.75 \\
\text { nd }\end{array}$ & $\begin{array}{l}7.21 \pm 1.26 \\
7.28 \pm 0.44 \\
\text { nd }\end{array}$ & $\begin{array}{l}3.99 \pm 0.64^{e)} \\
5.17 \pm 1.34^{e)} \\
\text { nd }\end{array}$ \\
\hline
\end{tabular}

All values are average of four analyses.

a) See the legend to Table I.

b) See the legend to Fig. 1 .

c) Fraction $\mathrm{A}, \mathrm{B}$ and $\mathrm{C}$ correspond to high molecular weight fraction $\left(\mathrm{V}_{\mathrm{e}} / \mathrm{V}_{0}=1.00\right)$, ceruloplasmin fraction (1.25)

and metallothionein fraction (1.78), respectively.

d) Significantly different from control group, $D<0.05$.

e) Significantly different from control group, $b<0.01$.

f) Result for pooled sample of each group.

nd : not determined.

TABLE VI. Subcellular Distribution ${ }^{b)}$ of Copper and Zinc in Renal Cytosol after Oral Administration of Cupric Compounds

( $\mu \mathrm{g}$ Metal $/ 0.8 \mathrm{~g}$ kidney)

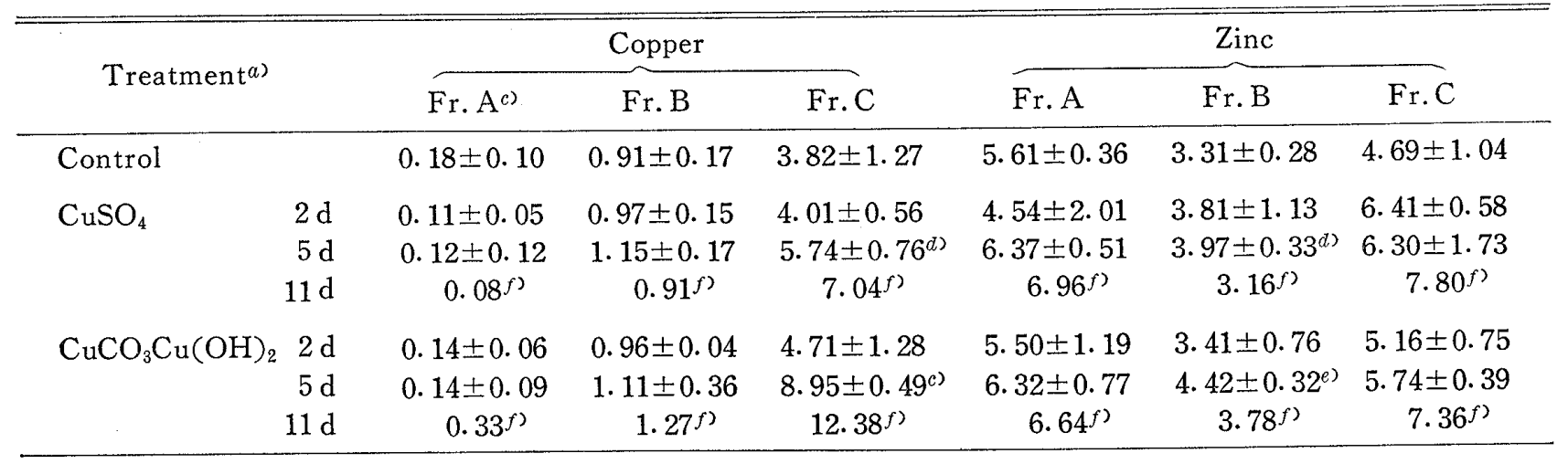

Legends are as described in Table $\mathrm{V}$.

なかった。

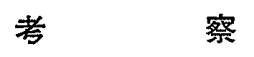

銅は食品中に広く含まれ，日本人は食品を通して毎日 平均 $1.60 \mathrm{mg}$ の銅を摄取している.6) また，銅は必須金 属としてWHO は成人に対し 1 日最低必要量を $50 \mu \mathrm{g} /$ $\mathrm{kg}$ 体重と勧告している. ${ }^{7}$ 一方, 銅を多量に摂取した場 合, 中毒症状を呈するが, 中毒発症量と最低必要量との 差が大きいため，あまり中毒事例は報告されていない。

一般に，鉰化合物の経口毒性は腸管からの吸収率によ って規定される，腸管からの吸収率は水及び腸液への溶 解度之強い負の相関関係がある，緑青の主成分である塩 基性炭酸銅は硫酸銅よりも水及び人工腸液への溶解度が はるかに小さい、したがって溶解度から考皇た場合，塩
基性炭酸銅の方が硫酸銅よりも毒性は低いと判断され る. 長橋 ${ }^{8)}$ は $\mathrm{LD}_{5},(24 \mathrm{~h})$ 值を硫酸銅 $240 \mathrm{mg} / \mathrm{kg}$, 塩 基性炭酸銅 $540 \mathrm{mg} / \mathrm{kg}$ 之報告し, ‘銅化合物の $\mathrm{LD}_{50}$ 值 は人工腸液及び水への溶解度と負の相関関係にあると報 告している. 秃, 銅化合物は一般に経口投与した場 合, 可溶性の塩の場合でも腸管からの吸収は悪く, 投与 した銅の80-90\%以上はとのまま排泄される. ${ }^{92}$ しか 乙，その一部は体内に取り込まれ特に肝臓中に蓄積す る. ${ }^{11,12)}$ 人工晹液の溶解度から, 硫酸銅々塩基性炭酸銅 の体内取り込又蓄積量を考光ると, 溶解度の小さい塩基 性炭酸銅の方が体内への蓄積量は硫酸銅よりる小さいと 推定されるが，今回の実験では塩基性炭酸銅投与群の方 が臓器中にはるかに高濃度の銅の蓄積をみた（Table 
II). 投与量は両化合物ともモル数としては $0.5 \mathrm{mmol} / \mathrm{kg}$ 体重と等しいが，銅の量としては塩基性炭酸銅の方が約 2 倍多い，それにしても臟器中には 2 倍以上の銅が蓄積 した.このことは塩基性炭酸銅には腸管から吸収され易 い何らかの機構が存在することを示するのと考兄る.

腸管から吸収された銅は血液中でアルブミンと結 合 し，体内を循環し肝蔵に取り込まれる，肝ミクロソーム でセルロプラスミンに合成され，再び血中に放出され体 内を循環する. ${ }^{13)}$ そこで血清中の銅の $95 \%$ がセルロプラ スミンに結合している14) とされている.しかし，Table II に示した如く，銅化合物投与によっても血中銅濃度 は顕著に增加することもなくまた血漿中の銅濃度は血 液中に占める割合も高くなく，また注とんど増加しなか った。これまで銅過剩投与によっても血液中の銅濃度は ほとんど変動しないとの報告15-17)があり，血中銅濃 度 が増加する時は肝壞死が伴 ${ }^{18-19)}$ という。このことか ら血中銅濃度は肝によりその恒常性が維持され，その維 持機能はかなり強力なるのと推定され，また今回の実験 の投与量では肝壊死を起こさなかったと考兄られる.

肝臟は銅の主要な貯蔵器官であるため，動物に銅を投 与すると肝臟中の銅濃度は20倍, ${ }^{11)} 45$ 倍, ${ }^{10)} 90$ 倍 ${ }^{12)}$ に増 加する，そして肝陚中では主にサイトソール画分に分布 するという報告20-222 がある一方，サイトソールと同時 にミトコンドリア・ライソソーム画分に銅が蓄積すると いう報告，10)李たミトコンドリア・ライソソーム画分に 最も多くの銅が蓄積するといら報告 ${ }^{23,24)}$ があり，銅の細 胞内分布については研究者によって若干異なっている。 これはサイトソールに分布した銅は時間とともに減少 し，10）それととるにミトコンドリア・ライソソーム画分

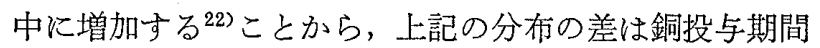
や銅投与から殺するでの時間の差によるものと考䒚られ る. 今回の実験では投与期間が長期になるに從い, Fig. 2 に示す如く，ミトコンドリア・ライソソーム画分中の 銅濃度は增加していった。このことから肝蔵に貯留する 銅の大部分はミトコンドリア・ライソソーム画分に貯 り，従って Goldfisher ${ }^{25}$ が示唆したようにこの 画分は 肝臓での銅の最終賩蔵部位と考兄られる。このミトコン ドリア・ライソソーム画分中に蓄積した銅は MT に由 来するものと考光られる.すなわち、ラインソームは

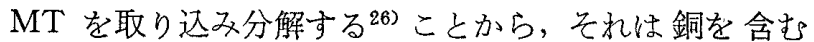
MTを取り达反, MTを分解した後, 銅を貯留するも

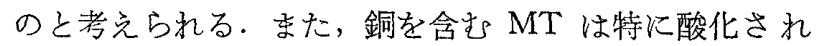
易い27)ため, 低温で分画しても MT が酸化され多量体 となり，それがミトュンドリア・ラインソーム画分に分 布年)したという可能性もある。

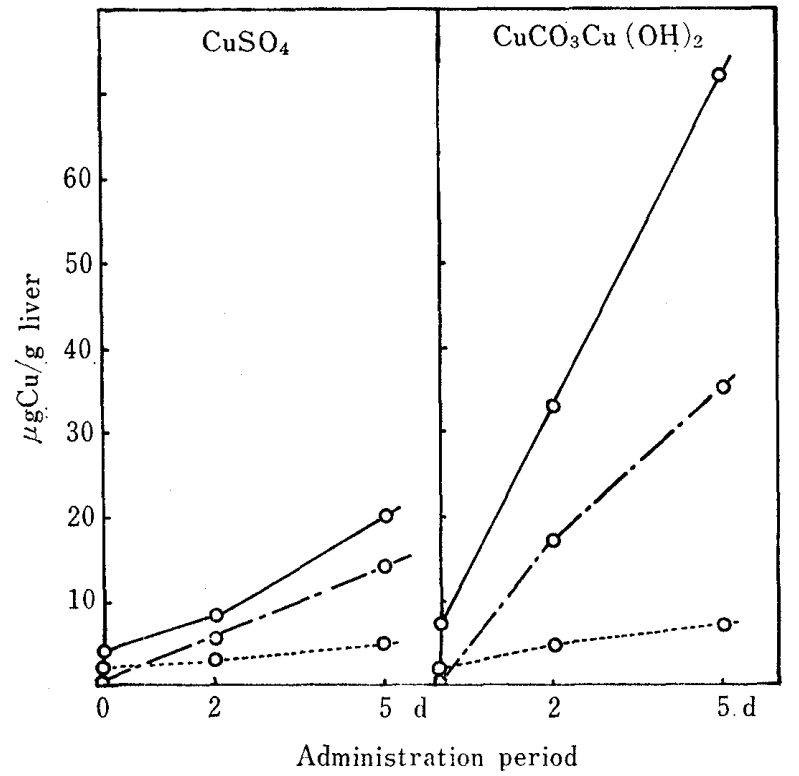

Fig. 2. Subcellular Accumulation of Copper in Liver after Administration of Cupric Compounds

The rat was treated and the subcellular fractions were divided as described in Fig. 1.

- liver, whole.

-... : mitochondrial fraction. ......... : cytosolic fraction.

対照群の婜臟には肝臓の約 2 倍の銅が含まれ，その約 $80 \%$ ガサイトソール画分に分布していた．この值は肝サ イトンール中の濃度よりもはるかに大きな値である。 ラットの腎 MT は他の臟器中の MT や他の動物の MT と違い銅含量が非常に高く，週令とともに MT 含量む 增加する27)ことから，サイトソール中の銅は MT に由 来するものと考觉られる．このサイトソール中の銅は銅 化合物投与によって11日後には対照群の 1.6-2.1 倍に 増加した。

ラット肝サイトソールを Sephadex G-100でゲルろ過 すると，銅は主に3つのピークに分れた。このゲルろ過 パターンは銅化合物投与のラット, ${ }^{10,30,43)}$ 牛, ${ }^{31)}$ 羊, ${ }^{32)}$ 山

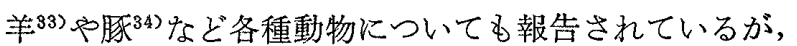
銅の投与方法や動物種によって銅の分布はかなり異なっ ている．最初のピークはオキシダーゼ活性よりセルロプ ラスミン $(\mathrm{CP})$ を含む画分で， $\mathrm{CP}$ は分子量 132000 の 蛋白， 1 モル当り 6 ケの銅原子を含む.35) またゲルろ過 画分についてスーパーオキサイドデスムターゼ（SOD） 活性を測定 ${ }^{36)}$ すると Fig.3 に示す如く，銅の第 2 の ピ ークは SOD 活性の溶出位置と一致した. SOD は以前 肝臓の銅眝蔵蛋白とみなされていたが，最近では組織中 に広く分布し， $\mathrm{O}_{2}^{-}$・ラジカルを分解し， $\mathrm{H}_{2} \mathrm{O}_{2}$ と $\mathrm{O}_{2}$ に 变觉る活性を有し，分子量 $34000 ， 0.34 \%$ の銅を含む ${ }^{372}$ 


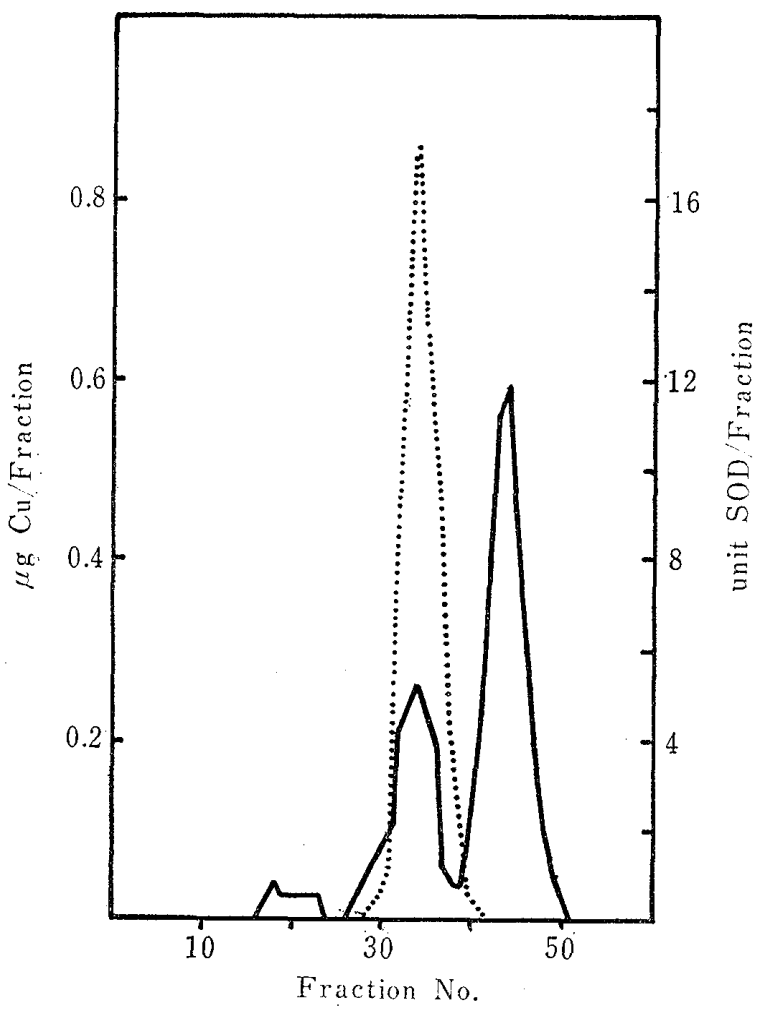

Fig. 3. Distribution of SOD Activity and $\mathrm{Cu}$ in Fractions Obtained after Gel-Filtration on Sephadex G-100

Rat was orally administered with cupric carbonate, basic on a dose of $0.5 \mathrm{mmol} / \mathrm{kg} / \mathrm{d}$ for $5 \mathrm{~d}$. The hepatic cytosol was prepared and gel-filtered as described in Fig. 1. SOD activity was assayed according to method of Beauchanp and Fridovich. ${ }^{36}$ )

$$
\text { - : Cu. ...... : SOD. }
$$

とされている．第 3 のピークは分子量と銅投与ラット肝 臓に MT が誘導合成されるという報告 $20,30,38-40)$ から， MTを含も画分と考えられる。銅は MT の主要な構成

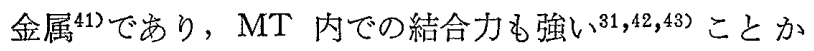
ら，銅化合物を投与することにより，投与された銅は MTを形成してC画分中に含まれるものと考㝋る. C 画分中の銅は硫酸銅投与 11 日後に対照動物群の25倍, 塩 基性炭酸銅投与により58倍にも増加した，MTは銅の細 胞内代謝で重要な役割を演じて拉り,30,39,40) 銅を先ず蓄 積してついで SODを含むB画分に銅を伝達するという が，今回の実騟ではB画分中の銅濃度はほとんど増加せ ず，C画分の銅濃度が増加するにとどまった．このこと は銅貯蔵蛋白とみなされていた SOD が銅の最終貯蔵蛋 白ではないことを示するのと考克る.一方，A画分中の 銅濃度もわずかながら增加した。この結果はこれまで報 告されている結果 ${ }^{30,45,46)}$ と同じであり，A画分にも高分
子の銅結合蛋白が存在する47)ものと考えられる．

また，肝サイトソール中の車鉛についてゲルろ過パタ ーンをみると，銅と異なって高分子画分（A画分）に最 も多く, ついでB画分に多く含まれ，こ机ら2つの画分 の覀鉛を合計すると $98 \%$ にも達した。これに銅化合物を 投与するとA画分及び B 画分中の亜鉛量はほとんど増加 しないのに坟し，MT 画分 (C画分) 中の亚鉛が有意 に（p<0.01）増加した。これは銅投与により MT が

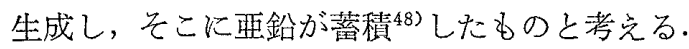

腎臓中の西鉛濃度は対照動物群に特いて肝臓中の亜鉛 濃度とほとんど同じであったが，その洓鈶の86\%はサイ トソール画分に分布していた：このサイトソールの G100 ゲルろ過パターンは肝蔵のそれとは異なり，分子量 約 10000 近辺に大きなピークが牥った。これは Suzu$\mathrm{ki}^{29}$ が指摘するように，本来存在している $\mathrm{Cu}, \mathrm{Zn}-\mathrm{MT}$ のピークと考党る。

銅は鉄代謝に深いかかわりを持ら，鉄が肝臓からへモ グロビン合成に移送される際に Fe(II)の Fe(III) への 酸化を触媒する. ${ }^{49,50)}$ 従って銅欠乏は貧血や肝蔵中の鉄

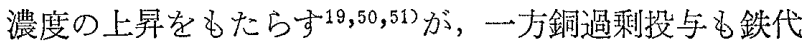
謝に影響を与え，鉄利用が低下することによりへモグロ ビン生産が低下する. ${ }^{52)}$ な, ヒトでは肝，㛑の障害，メ トへモグロビン血症, ${ }^{50,53)}$ 豚では鉄吸収阻害による小赤 血球低色素性貧血, ${ }^{19,52)}$ 羊では肝壊死につついて肝臟か らの銅の遊出，血中銅濃度の增加，メトへモグロビン血 症, 溶血 ${ }^{17,54)}$ が報告されている. しかし，今回の実験で は血液及び藏器中の鉄濃度にはほとんど影響が認められ ず，從って $0.5 \mathrm{mmol} / \mathrm{kg}$ 体重の投与量はラットの鉄代 謝にほとんど影響を与去なかったと考劣る。

以上の結果をま之めると，塩基性炭酸銅は硫酸銅に比 較主ると体内に多量に取り达囬れ，特に肝臓中に多く蓄 積した。として肝細胞中では投与期間とともにミトコン ドリア・ライソソーム画分に銅が一番多く蔡積し，この 画分は銅の最終貯蔵部位と考兄られた。 また，サイトソ 一ル画分中では SOD 画分より，先しろMT 画分に蓄積 した．肝臓中の亜鉛量は銅化合物投与により増加し，そ の増加はサイトソール画分に顕著であった。一方, 血液, 蔵器中の鉄濃度は銅化合物投与によってもほとんど変動 がみられず，塩基性炭酸銅 $0.5 \mathrm{mmol} / \mathrm{kg} 11$ 日間投与で は鉄代謝に大きな影響をもたらさないものと思われる。

謝辞本研究の一部は厚生省食品簿生研究費によっ て行なった。 


\section{引用文 献}

1) 厚生省告示第370号, 食品添加物等の規格基準 (1959).

2）厚生省令第36号，昭和58年 8 月 27 日。

3) R.G. Helman, L.G. Adams, K.R. Pierce, C.H. Bridges, E. M. Bailey, Toxicol. Appl. Pharmacol., 67, 238 (1983).

4) S. Lal, T.L. Sourkes, Toxicol. Appl. Pharmacol., 18, 562 (1971).

5) G. Gregoriadis, T.L. Sourkes, Can. J. Biochem., 45, 1841 (1967).

6)山県 登。“微量元素,”産業図畫, 東京, 1977. p. 183.

7) WHO, WHO Technical Report Serirs, No. 532 (1973).

8）長橋 捷, 和由 攻, 小野 哲, 岩井秀明, 山口喜久, 野口 戟, 日衛試, 31, 129 (1976).

9) C.A. Owen, Am. J. Physiol., 207, 1203 (1964).

10) T. Kassanov, E. Russanov, Bulg. Acad. Sci., 4, 13 (1978).

11) C.A. Owen, J.B. Hazelrig, Am. J. Physiol., 215, 334 (1968).

12) S. Lal, R. Papeschi, R.J.S. Duncan, T.L. Sourkes, Toxicol. Appl. Pharmacol., 28, 395 (1974).

13) N. Marceau, N. Aspin, Biochim. Biophys. Acta, 328, 351 (1973).

14) C.G. Holmberg, C. B. Laurell, Acta Chem. Scand., 5, 921 (1951).

15) G.W. Evans, Physiol. Rev., 53, 535 (1973).

16) G.S. Shields, H. Morkowitz, w.H. Klassen, G.E. Cartwright, M.M. Wintrobe, J. Clin. Invest., 40, 2007, (1961).

17) E.C. Theil, K.T. Calvert, Biochem. J., 170, 137 (1978).

18) C. Gopinath, J. McC. Howell, Res. Vet. Sci., 19, 35 (1975).

19) W.F. Gipp, W.G. Pond, J. Tasker, D. V. Campen, L. Krook, W. J. Visek, J. Nutr., 103, 713 (1973).

20) H. Suzuki, O, Wada, Ind. Health, 20, 35 (1982).

21) R.E. Thiers, B.L. Valee, J. Biol. Chem., 226, 911 (1957).

22) R.G. Helman, L.G. Adams, K.R. Pierce, C.H. Bridges, E.M. Bailey, Toxicol. Appl. Pharmacol., 67, 238 (1983).

23) S. Goldfischer, E. Sternlieb, Am. J. Pathol., 53, 883 (1968).

24) G.W. Evans, Physiol. Rev., 53, 535 (1973).

25) S. Goldfisher, Am. J. Pathol., 46, 977 (1965).

26) S.L. Feldman, M.L. Failla, R.J. Cousins, Biochim. Biophys. Acta, 544, 638 (1978).

27) K.T. Suzuki, M. Yamamura, T. Maitani, J. Lig. Chromatogr., 3, 1385 (1980); T. Maitani, Biochem. J., 199, 289 (1981).

28) H. Porter, Biochem. Biophys. Res. Commun., 56, 61 (1974).

29) K.T. Suzuki, M. Yamamura, Toxicol. Lett., 6, 301 (1980); K.T. Suzuki, K. Kubota, S. Takenaka, Chem. Pharm. Bull., 25, 2792 (1977).

30) T. Terao, C. A. Owen, Jr., Tohoku J. Exp. Med., 120, 209 (1976).

31) I. Bremner, R.B. Marshall, Br. J. Nutr., 32, 293 (1974); idem, ibid., 32, 283 (1974).

32) G. Norheim, N.E. Soli, Acta Pharmacol. Toxicol., 40, 178 (1977).

33) M.M. Grimsrud, N.E. Soli, T. Silvertsen, Acta Pharmacol. Toxciol., 44, 319 (1979).

34) I. Bremner, Br. J. Nutr., 35, 245 (1976); A. Froslie, G. Norheim, Acta Vet. Scand., 18, 471 (1977).

35) E. Frieden, "Biological Roles of Copper," Excerpta Medica, Amsterdam, 1980, p. 94.

36) C. Beauchamp, I. Fridovich, Anal. Biochem., 44, 276 (1971).

37) J.M. NcCord, I. Fridorich, J. Biol. Chem., 244, 6049 (1969).

38) A.E. Port, D. M. Hunt, Biochem. J., 183, 721 (1979).

39) F.A. Day, M. Panemangalore, F. A. Brady, Proc. Soc. Exp. Biol. Med., 168, 306 (1981).

40) T. Terao, C. A. Owen, Am. J. Physiol., 224, 682 (1973).

41) R.D. Irons, J.C. Smith, Chem. Biol. Interact., 15, 289 (1976); I. Bremner, Br. J. Nutr., 35, 245 (1976).

42) A.D. Garnica, W.Y. Chan, O.M. Rennert, Ann. Clin. Lab. Sci., 8, 302 (1978).

43) I. Bremner, R. K. Mehra, Chem. Scr., 21, 117 (1983).

44) I. Bremner, N.T. Davies, Br. J. Nutr, 36, 101 (1976). 
45) K.T. Suzuki, M. Yamamura, Arch. Environ. Contam. Toxicol., 8, 471 (1979).

46) I. Bremner, "Biological Roles of Copper," Excerpta Medica, Amsterdam, 1980, p. 41.

47) V. Wesen, H. Rupp, F. Donay, F. Linnemann, W. Veelter, W. Voetsch, G. Jung, Eur. J. Biochem., 39, 127 (1973).

48) K.T. Suzuki, M. Yamamura, Toxicol. Lett., 6, 301 (1980).

49) E. Frieden, H.S. Hsieh, Adv. Enzymol., 44, 187 (1976).

50) J.L. Evans, P.A. Abraham, J. Nutr., 103, 196 (1973).

51) E.B. Hart, H. Steenbock, J. Waddel, C.A. Elvehjem, J. Biol. Chem., 77, 797 (1928).

52) M.F. Gipp, W.G. Pond, F.A. Kallfelz, J.B. Tasker, D.R.V. Campen, L. Krook, W. J. Visek, J. Nutr., 104, 532 (1974).

53) K.S. Chugh, P.C. Singhal, B.K. Sharma, Ann. Intern. Med., 82, 226 (1975).

54) J.R. Todd, R.H. Thompson, Nature (London), 191, 89 (1961). 